\title{
Profil Kejujuran Anak Usia 5-6 Tahun di RA-At-Taufiq Kota Tasikmalaya
}

\author{
Yasbiati, Edi Hendri Mulyana, Taopik Rahman, Qonita \\ Pendidikan Anak Usia Dini, Fakultas Ilmu Pendidikan, Universitas Pendidikan Indonesia \\ Jalan Dadaha No. 18 Kota Tasikmalaya, Indonesia \\ E-mail: yasbiati@upi.edu,edihm@upi.edu, qonita1993@student.upi.edu
}

\begin{tabular}{|c|c|}
\hline ARTICLE INFO & ABSTRACT \\
\hline $\begin{array}{l}\text { Article history: } \\
\text { Received: 9-12-2019 } \\
\text { Revised: 16-12-2019 } \\
\text { Accepted: 23-12-2019 } \\
\text { Keywords: } \\
\text { Pendidikan Karakter, } \\
\text { Karakter Anak, Kejujuran }\end{array}$ & 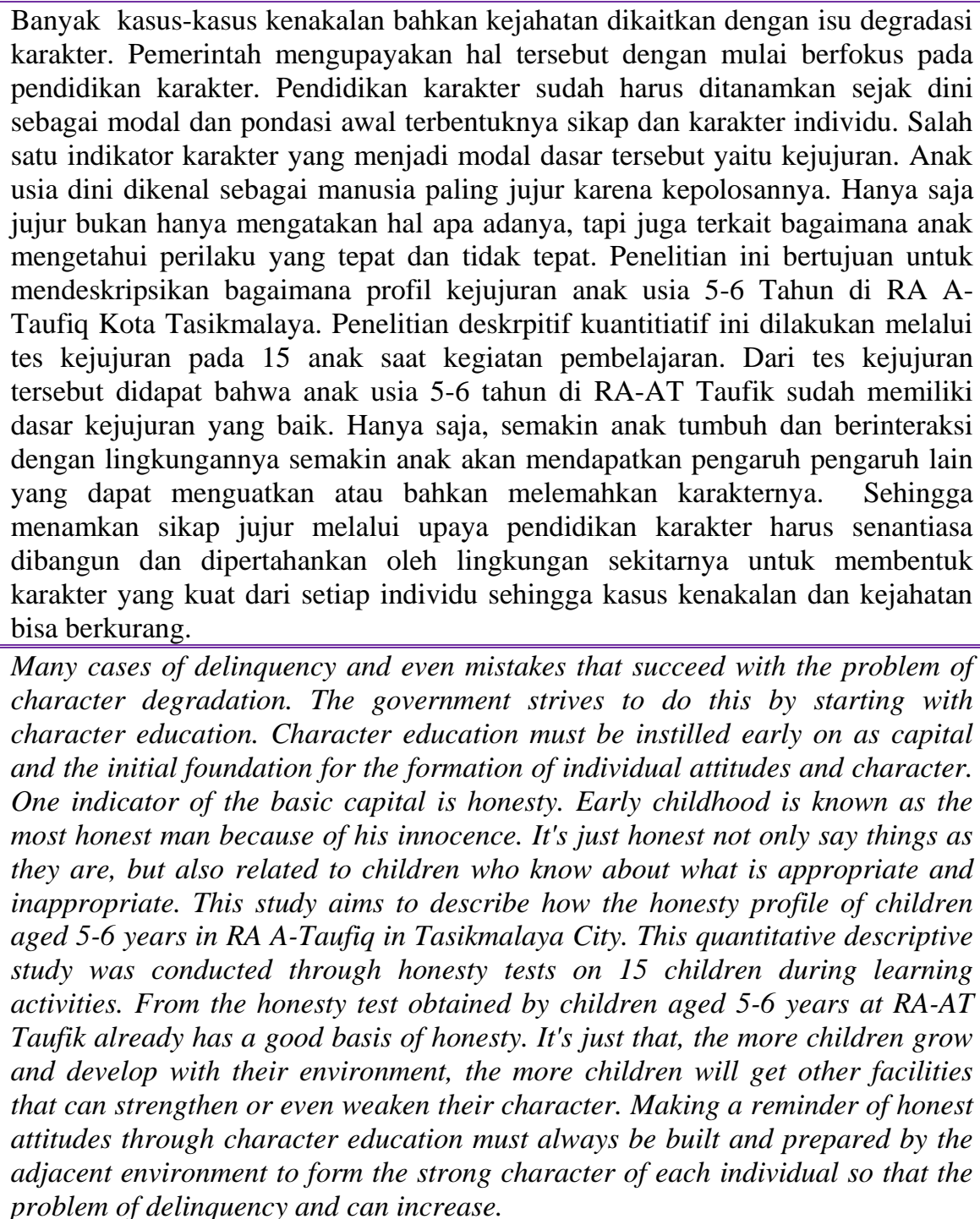 \\
\hline
\end{tabular}

\section{PENDAHULUAN}

Menurut Sujiono (2010, hlm. 7) Hakikat anak usia dini atau yang di singkat AUD adalah anak berusia 0 sampai 6 tahun yang membentuk karakter dan kepribadian anak. Dalam proses pembentukan kepribadian dan karakter anak perlu diberikan suatu rangsangan dari orang dewasa berupa bimbingan dan arahan agar perkembangan anak bisa optimal. Para ahli memandang pendidikan anak usia dini merupakan masa emas (the golden age) dan periode sensitif (sensitive periods), pada masa ini anak secara khusus mudah menerima berbagai stimulus yang diberikan oleh lingkungannya. Para ahli memandang pendidikan anak usia dini merupakan masa emas (the golden age) dan periode sensitif 
(sensitive periods), pada masa ini anak secara khusus mudah menerima berbagai stimulus yang diberikan oleh lingkungannya.

Dalam Permendikbud Nomor 146 tahun 2014 dijelaskan bahwa: "Penelitian menunjukkan bahwa masa peka belajar anak dimulai dari anak dalam kandungan sampai 1000 hari pertama kehidupannya. Menurut ahli neurologi, pada saat lahir otak bayi mengandung 100 sampai 200 milyar neuron atau sel syaraf yang siap melakukan sambungan antar sel. Sekitar 50\% kapasitas kecerdasan manusia telah terjadi ketika usia 4 tahun, $80 \%$ telah terjadi ketika berusia 8 tahun, dan mencapai titik kulminasi $100 \%$ ketika berusia 8 sampai 18 tahun". Berdasarkan penjelasan di atas dapat diketahui bahwa rangsangan kepada anak yang lahir sampai usia 8 tahun sangalah penting karena pada masa tersebut perkembangan neuron atau otak anak dapat opimal yang akan sangat berpengaruh terhadap perkembangan anak selanjutnya dan berimbas pada kehidupannya dimasa yang akan datang.

Merujuk pada undang - undang Nomor 20 tahun 2003 dijelaskan bahwa PAUD adalah suatu upaya pembinaan yang ditujukan kepada anak sejak lahir sampai dengan usia 6 tahun yang dilakukan melalui rangsangan pendidikan untuk membantu pertumbuhan dan perkembangan jasmani dan rohani agar anak memiliki kesiapan belajar dalam memasuki pendidikan lebih lanjut. Pendidikan anak usia dini memiliki salah satu prinsip yaitu belajar sambil bermian atau bermain seraya belajar. Artinya dalam pembelajaran anak usia dini harus diciptakan dalam situasi yang nyaman, senang, tanpa tekanan seperti anak sedang melakukan kegiatan bermain. Dalam permendikbud (2014) dijelaskan bahwa "pembelajaran anak usia dini mencakup 6 (enam) lingkup aspek perkembangan yaitu, perkembangan nilai agama dan moral, perkembangan fisik-motorik, perkembangan kognitif, perkembangan bahasa, perkembangan sosial-emosional dan perkembangan seni" yang dimuat dalam bentuk tema. Setiap lingkup perkembangan yang dialami anak pasti mengalami hambatan yang berbeda termasuk dalam lingkup perkembangan nilai agama dan moral yaitu karakter jujur. Kemendikbud (2014) dijelaskan karakter jujur mencakup jujur dalam perkataan dan perbuatan.

Indonesia saat ini sedang dihangkatkan oleh isu degradasi moral anak bangsa. Banyaknya laporan tindak kenakalan anak hingga remaja memicu reaksi publik untuk menyoroti bagaimana pendidikan karakter di Indonesia khususnya di persekolahan. Hal ini nampak dalam beragam tulisan di media massa, seperti pada laman Kompasiana pada 9 Februari 2018 dalam artikel yang berjudul "Degradasi Moralalitas Genmud sebagai Penanda Buruknya Pendidikan Karakter di Indonesia". Dalam artikelnya dikatakan bahwa degradasi moral banyak diasumsikan sebagai kegagalan pendidikan karakter, karena orientasi pendidikan saat ini lebih cenderung berfokus pada hal yang berkaitan dengan capaian akademis.

Namun seperti yang kita ketahui bahwa capaian akademis saja tidak cukup untuk kehidupan di masa yang akan datang, tetapi karakter anak ikut andil di dalamnya. Karakter merupakan aspek penting sebagai pondasi bagi mentalitas serta kesuksesan manusia di masa mendatang. Karakter sendiri berasal dari akar kata bahasa latin yang berarti "dipahat" dan bahasa Yunani "Charassian" yang berarti menandai dan memfokuskan bagaimana mengaplikasikan suatu nilai dalam bentuk tingkah (Aeni, dkk, 2017, hlm.12). Karakter juga diartikan sebagai kualitas mental atau moral, kekuatan moral, nama, atau reputasinya. Sedangkan secara psikologi karakter adalah kepribadian ditinjau dari titik tolak etis atau moral dengan sifat sifat yang relatif tetap. Selain itu juga Lickona (Aeni, dkk, 2017, hlm.12) memaparkan bahwa pendidikan karakter adalah upaya yang disengaja untuk membantu orang memahami, peduli, dan bertindak berdasarkan nilai-nilai etika inti untuk mendukung perkembangan sosial, emosional dan etis.

Karakter yang diinternalisasikan dalam dunia pendidikan pertama kali dicetuskan oleh FW. Foerster yang merupakan sebuah usaha untuk mengidupkan kembali pedagogi yang mengacu pada pada pendekatan idealis-spirutualis dalam Pendidikan (Asmani,2011, hl. 27). Lickona (Aeni, dkk, 2017, hlm.12) memaparkan bahwa pendidikan karakter adalah upaya yang disengaja untuk membantu orang memahami, peduli, dan bertindak berdasarkan nilai-nilai etika inti untuk mendukung perkembangan sosial, emosional dan etis.

Pendidikan karakter sangat diharapkan dapat ditanamkan dan ditumbuhkan sejak dini sebagai pondasi awal mereka dalam mengembangkan kehidupan sosial nya. Salah satu aspek dari karakter yang penting di tanamkan sejak dini adalah kejujuran. Sikap jujur anak ini mulai muncul sejalan dengan tumbuhnya kemampuan anak untuk berinteraksi dan menjalin hubungan dengan orang lain, munculnya harapan pada diri anak, dan memahami perilaku yang dapat diterima atau tidak dapat diterima (VanderVen, 2008). Anak usia dini harus diberikan pendidikan karakter yang sesuai dengan 
perkembangan usianya. Sekolah sebagai wahana pembelajaran tak diragukan berperan besar dalam perkembangan karakter siswa dan melalui PAUD kita dapat merubah moral bangsa. Usia dini merupakan masa keemasan bagi anak sehingga PAUD memegang peranan penting dalam menentukan perkembangan anak selanjutnya sebagai pondasi dasar kepribadian anak.

Anak usia dini dikenal sebagai manusia paling jujur yang artinya Kesuma (2011, hlm. 16) menambahkan bahwa jujur merupakan keputusan seseorang untuk mengungkapkan dalam bentuk perasaan, perkataan, dan perbuatan sesuai dengan realitas yang ada dan tidak memanipulasi dengan berbohong atau menipu untuk keuntungan dirinya. Namun seiring perkembangan sosial anak dalam berinteraksi dengan orang lain dan mengenal lingkungannya sangat berpengaruh terhadap kejujuran anak. Hal tersebut karena anak berkembang dan berubah sesuai dengan kematangan dan pengalaman yang didapatnya.(Mansur, 2007).

Hasil penelitian terdahulu menunjukan bahwa anak-anak mulai berbohong sejak usia 2 hingga 3 tahun untuk menyembunyikan kesalahan mereka. Seiring bertambahnya usia, kebohongan anak menjadi semakin kompleks dan mereka memiliki cara yang hebat untuk menyembunyikannya, dan pada akhir masa kanak-kanak orang dewasa sudah tidak bisa membedakan lagi apakah anak jujur atau berbohong (Lee et.al, 2014). Berdasarkan latar belakang dan kajian literatur di atas maka dapat dirumuskan masalahnya sebagai berikut "Bagaimana profil kejujuran anak usia 5-6 tahun di R A AtTaufiq Kota Tasikmalaya”. Dari perumusan masalah maka tujuan penulisan adalah untuk mendeskripsikan profil kejujuran anak usia 5-6 tahun di RA At-Taufiq Kota Tasikmalaya.

\section{METODE}

Metode penelitian yang digunakan dalam penelitian ini adalah deskriptif kuantitatif untuk mendeskripsikan sejauh mana sikap jujur yang sudah tertanam pada anak. Menurut Sugiyono (2010: 29), analisis deskriptif merupakan analisis statistik yang digunakan untuk menganalisis data dengan cara mendeskripsikan atau menggambarkan data yang telah terkumpul. Jenis data yang digunakan dalam penelitian ini adalah data kuantitatif yang dinyatakan dalam angka dan dianalisis dengan teknik statistik. Selain itu, penelitian deskroptif adalah penelitian yang memberikan gambaran lebih detail mengenai suatu gejala berdasarkan data yang ada, menyajikan data, menganalisis, dan menginterpretasi (Narbuko\& Achmadi, 2003). Sampel yang diambil merupakan sampel jenuh, yaitu seluruh anak kelompok umur 5-6 Tahun di TK At-Taufiq sebanyak 15 anak. Data dikumpulkan melalui tes yang disetting dalam kegiatan pembelajaran agar anak tidak menyadari bahwa mereka sedang diobservasi. Data diukur berdasarkan lembar observasi yang telah teruji validitas dan reliabilitasnya.

\section{HASIL DAN PEMBAHASAN}

\section{Hasil}

Profil karakter jujur anak di kelompok usia 5-6 tahun di RA-At-Taufik Kota Tasikmalaya didapatkan melalui test kejujuran yang dilakukan secara berkelompok dalam kegiatan pembelajaran. Tes dilakukan dengan menggunakan beragam makanan yang dimasukan kedalam toples yang tertutup. Kemudian guru mengarahkan anak untuk tidak membuka terlebih dahulu toples tersebut sebelum guru memperbolehkannya. Guru meninggalkan anak-anak selama \pm 10 menit dan aktivitas anak dipantau melalui kamera. Setelah masuk kembali guru bertanya kepada anak tentang apa yang terjadi selama guru diluar kelas. Di bawah ini adalah skor kejujuran anak setelah memperoleh perlakuan dari guru.

Tabel 1. Skor Kejujuran Anak

\begin{tabular}{ccl}
\hline Kode Anak & Skor & Kategori \\
\hline 1 & 9 & Sangat Baik \\
2 & 6 & Baik \\
3 & 6 & Baik \\
4 & 9 & Sangat Baik \\
5 & 6 & Baik \\
6 & 8 & Sangat Baik \\
7 & 8 & Sangat Baik \\
8 & 9 & Sangat Baik \\
9 & 4 & Cukup \\
10 & 4 & Cukup \\
\hline
\end{tabular}




\begin{tabular}{rrl}
\hline 11 & 4 & Cukup \\
12 & 6 & Baik \\
13 & 6 & Baik \\
14 & 6 & Baik \\
15 & 8 & Sangat Baik \\
Rata-Rata & 6,6 & Baik \\
\hline
\end{tabular}



Diagram 1. Perbadingan Kejujuran berdasarkan Indikator

\section{Pembahasan}

Kejujuran sangat penting sebagai dasar terjadinya hubungan interaksi yang harmonis antar individu atau kelompok. Kejujuran menciptakan komunikasi yang baik, sehingga timbul rasa saling percaya (Aeni,dkk, 2017, hlm.41). Menurut Direktorat Jenderal Pendidikan Anak Usia Dini Nonformal dan Informal (2012) terdapat beberapa indikator nilai karakter jujur yaitu anak mengerti mana milik pribadi dan milik bersama, anak merawat dan menjaga benda milik bersama, anak terbiasa berkata jujur, anak terbiasa mengembalikan benda yang bukan miliknya, menghargai milik bersama, mau mengakui kesalahan, meminta maaf jika salah, dan memaafkan teman yang berbuat salah, dan menghargai keunggulan orang lain. Namun dalam penelitian ini ada 9 indikator yang dijadikan penilaian kejujuran anak yaitu (1) anak tidak menuduh orang lain atau mengatakan hal yang tidak benar terkait orang lain, (2) anak tidak menutupi kesalahan yang dilakukannya, (3) anak menjelaskan peristiwa sesuai fakta, (4) anak dapat mematuhi aturan, (5) anak tidak mengambil sesuatu yang bukan miliknya, (6) anak meminta izin saat menggunakan/mengambil barang yang bukan miliknya, (7) anak mengembalikan barang yang dipinjam, (8) anak mengetahui perbuatan yang tepat dan tidak tepat, (9) menyadari dan mengakui kesalahannya.

Sehubungan dengan temuan hasil penelitian di atas, terdapat beberapa kejujuran anak yang berbedabeda. Hal tersebut dapat terlihat dari tabel.1 yaitu mengenai kejujuran anak. Dari 15 orang anak yang diteliti terdapat 3 orang anak yang memperoleh skor 9 yang artinya sangat baik. 3 anak yang memperoleh skor 8,6 anak yang memperoleh skor 6, dan 3 orang anak yang memperoleh skor 4. Kategori skor yaitu: 1-3,5 Kurang, 3,6 - 5,5 Cukup, 5,6 - 7,5 Baik, dan 7,6 - 9 Sangat Baik. Tahapan ini berlandas pada perkembangan karakter jujur anak berdasarkan rubrik penilaian sesuai dengan data yang didapat. Paling banyak anak menunjukan 6 indikator dan paling sedikit anak menunjukan 9, 8, dan 4 indikator. Di tabel 1 menunjukkan bahwa nilai rata-rata skor kejujuran anak adalah 6,6 yang artinya bahwa kejujuran anak baik.

Selain itu juga, dari diagram 1 menunjukan perbandingan indikator kejujuran yang dicapai oleh anak. Diagram tersebut menjelaskan dari sembilan indikator kejujuran yang dimiliki anak yang paling minim adalah menyadari dan mengakui kesalahannya. Hal tersebut karena anak baru berkembang sesuai perkembangan usianya, maka ketika anak menyadari punya kesalahan anak tidak meyadari dan tidak mengakui kesalahannya malah anak akan menunjukan ekspresi takut yaitu takut dimarahi dan takut dihukum (Novriyansah, dkk, 2017). Oleh karena itu, sebagai orang dewasa jika anak mengakui kesalahannya, jangan langsung dimarahi tetapi hargai kejujurannya setelah itu kita bisa meluruskan kesalahan anak sehingga anak akan terbiasa untuk bicara jujur. Karena hal yang paling menakutkan adalah ketika anak sudah terbiasa dengan berkata tidak jujur dan sulit untuk mengakui kesalahannya, oleh karena itu Novriyansa dkk (2017, hlm. 1) menjelaskan bahwa anak sejak dini harus membiasakan 
diri jujur sebagai bekal kesiapan adaptasi dan sosialisasi pada jenjang pendidikan lebih lanjut. Jika kita melihat ke waktu yang lebih panjang atau ke waktu yang akan datang, hal tersebut dapat menjadikan benih untuk melakukan korupsi sebagai praktik pelanggaran moral seperti ketidakjujuran tidak tanggung jawab, rendahnya disiplin, rendahnya komitmen kepada nilai-nilai kebaikan (Megawangi, 2004).

Nilai kejujuran penting ditanamakan sejak masa anak-anak. Anak merupakan pribadi yang masih bersih dan peka terhadap rangsangan dari lingkungan luar. Orang tua dan guru memiliki peran penting untuk menanamkan nilai kejujuran pada anak, karena mereka adalah orang paling dekat dan mempengaruhi pertumbuhan anak. Terdapat beberapa cara menanamkan kejujuran pada anak yakni menanamkan kejujuran dengan cerita, memberikan pujian dan penghargaan secara terbuka, menyikapi kesalahan anak dengan baik, memberikan pemahaman dengan lembut, memberikan perhatian dan kasih sayang, menanamkan kejujuran melalui diskusi, dan membiasakan berkata dan bersikap jujur kepada anak. Hal tersebut dapat dilakukan agar anak terbiasa berkata dan berbuat jujur. Membentuk sikap jujur anak membutuhkan beberapa pihak yang mendukung untuk ketercapaian tersebut salah satunya peran orang tua. Oleh karena itu, Baumrind (1971) dalam Santrok (2007) menyatakan bahwa terdapat empat jenis gaya pengasuhan yang dapat dilakukan oleh orang tua yaitu: (1) Pengasuhan otoritarian yaitu gaya yang membatasi dan menghukum sehingga orang tua mendesak anak untuk mengikuti arahan mereka dan menghormati pekerjaan dan upaya mereka, (2) Pengasuhan otoritatif yaitu mendorong anak untuk mandiri namun masih menerapkan batas dan kendali pada tindakan mereka, (3) Pengasuhan yang mengabaikan yaitu gaya pengasuhan dimana orang tua tidak terlibat dalam kehidupan anak, dan (4) Pengasuhan menuruti yaitu gaya pengasuhan dimana orang tua sangat terlibat dengan anak, namun tidak terlalu menuntut atau mengotrol mereka. Dari beberapa gaya pengasuhan di atas, sebagai orang tua kita harus memberikan pengasuhan yang tepat untuk anak, agar karakter jujur anak dapat terbentuk. Jika pengasuhan orang tua tidak tepat, maka dikhawatirkan karakter kejujuran anak tidak akan terbentuk di dalam diri anak.

Beberapa gaya pengasuhan yang dipaparkan oleh Baumrind, tentunya memberikan pengaruh bagi anak atau sumbangan bagi perkembangan anak. Seperti yang dipaparkan oleh Hurlock (2013) bahwa terdapat beberapa sumbangan keluarga pada perkembangan anak diantaranya: (1) perasaan aman karena menjadi anggota keluarga kelompok yang stabil, (2) orang-orang yang dapat diandalkan dalam memenuhi kebutuhannya, (3) sumber kasih sayang dan penerimaan yang tidak terpengaruh oleh apa yang mereka lakukan, (4) model pola perilaku yang disetujui guna belajar menjadi sosial, (5) bimbingan dalam pola perkembangan perilaku, (6) orang yang dapat diharapkan bantuannya dalam memecahkan masalah yang dihadapi anak, (7) bimbingan dan bantuan dalam mempelajari percakapan (8) perangsang kemampuan untuk mencapai keberhasilan di sekolah dan kehidupan sosial, dan (9) bantuan dalam menetapkan aspirasi yang sesuai dengan minat dan kemampuan. Pemaparan di atas, mengenai gaya pengasuhan dan sumbangan keluarga bagi perkembangan anak dapat terwujud ketika keluarga berusaha menyempatkan waktu untuk melakukan perannya bagi perkembagan anak. Hal tersebut seperti dikemukakan oleh Cooper, dkk. (2009) bahwa ketika seluruh anggota keluarga menghabiskan waktu bersama, mereka menciptakan sebuah identitas bersama sekaligus menyimpan kenangan yang indah; sebuah landasan untuk membantu anak-anak memiliki konsep tentang siapa mereka dan perasaan memiliki. Oleh karena itu, setiap anggota keluarga diharapkan untuk meluangkan waktu dan memiliki waktu khusus bersama anak agar anak merasa dihargai dan dianggap ada sehingga pembentukan karakter anak akan mudah dilakukan ketika orang tua dan anak memiliki kedekatan yang cukup erat.

Dalam mendidik anak, keluarga atau orang tua ada banyak peran yang akan mempengaruhi pola pikir dan perilaku dari seorang anak (Rofiq\& Ismatun): (1) orang tua dapat memberikan penjelasan mengenai hal baik dan buruk bagi anak, penting bagi anak untuk mendapat penjelasan terhadap kelakuan itu boleh dilakukan. (2) pendidikan yang keras juga akan menyebabkan anaknya menjadi keras, menggunakan pola pendidikan yang keras akan menyebabkan anak-anak menjadi disiplin, namun malah juga akan meningkatkan kemungkinan seorang anak untuk tidak nyaman. (3) apa yang dilakukan orang tua akan ditiru oleh anak, anak akan mengikuti apa yang menjadikan kebiasaan orang tuanya. Jadi dalam mendidik anak untuk memiliki karakter yang baik, orang tua harus memberi contoh yang positif kepada anak baik dalam tingkah laku atau berbicara. (4) orang tua harus bisa menjaga anaknya dari lingkungan social yang buruk. Apabila orang tua sudah mendidik anaknya dengan baik, maka disamping itu orang tua harus bisa menjaga atau mengawas anaknya dalam 
kehidupan bersosial. (5) memberi kasih saying dan semangat, orang tua harus memberi kasih sayang dan menghargai anak, baik di saat mereka mendapatkan nilai ujian yang bagus maupun ketika mereka tidak mendapat hasil yang diinginkan karena sesungguhnya mereka telah bekerja keras.

Selain peran orang tua, sekolah juga memiliki peran dalam pembentukan karakter kejujuran anak. Peran sekolah dalam menanamkan nilai kejujuran pada anak sangat penting, dengan selalu memberi contoh atau perilaku yang jujur secara langsung akan menumbuhkan nilai kejujuran yang tinggi dan rasa tanggungjawab yang akan berguna bagi dirinya baik di masa sekarang maupun yang akan datang (Messi \& Edi, 2017). Dalam rangka penanaman nilai-nilai kejujuran di sekolah, ada beberapa peran yang dapat dilakukan oleh guru (Amin, 2017), yaitu: (1) Memberikan pengajaran secara terus menerus dan terintegrasi yaitu peran guru dalam menanamkan nilai kejujuran kepada peserta didik dengan cara memberikan pengetahuan melalui pengajaran secara terus menerus dan memadai tentang kejujuran. Misal, pengetahuan tentang apa yang dimaksud dengan jujur, mengapa seseorang harus berbuat jujur, dan apa konsekuensi jika seseorang tidak jujur. Namun demikian, pengajaran yang diberikan oleh guru tersebut haruslah terintegrasi. Artinya bukan hanya dilakukan satu orang guru atau guru agama saja, tetapi harus seluruh guru yang ada di sekolah tersebut, dan dilakukan pada setiap pembelajaran. Selain itu, pengajaran yang diberikan oleh guru hendaklah secara terus menerus pada setiap kesempatan, bukan saja pada pembelajaran di kelas, tetapi juga di luar kelas dengan memberikan pengajaran tersebut, maka peserta didik akan terbentuk dalam dirinya untuk bertindak dan bertanggung jawab terhadap setiap tindakannya. Jika ia telah mengetahui dan memahami tentang kejujuran, ia akan berbuat jujur, dan jika ia berbuat tidak jujur, maka ia pun tahu akan konsekuensi dari setiap ketidakjujurannya. (2) Memberikan keteladanan yaitu dalam kehidupan di masyarakat, terkadang banyak kita temukan orang yang suka menyampaikan kebaikan-kebaikan dan contoh-contoh perbuatan yang baik. Namun terkadang pula, sulit untuk menemukan orang- orang yang menjadi contoh perilaku kebaikan. Dalam hal penanaman nilai kejujuran, seorang guru bukan sekedar menyampaikan pengetahuan tentang kejujuran itu, tetapi guru hendaklah berperan sebagai orang yang berperilaku jujur. Artinya bahwa seorang guru hendaklah berbuat kejujuran itu dimulai dari diri sendiri dan menjadi teladan kejujuran bagi anak didiknya, dan terlihat nyata dalam setiap sikap dan tindakannya, sehingga pada gilirannya akan ditiru oleh anak didiknya. (3) Membiasakan berperilaku yaitu Suatu ungkapan yang patut untuk direnungkan adalah "sesuatu itu bisa karena biasa". Hal ini mengindikasikan bahwa setiap perilaku individu dalam kehidupan sehari-hari karena kebiasaan. Begitupun tentang kejujuran. Seseorang tentu tidak akan mampu berperilaku jujur jika tidak membiasakan diri untuk berbuat jujur. Untuk itu, selain memberikan pengetahuan tentang kejujuran, maka guru hendaknya berupaya pula membiasakan peserta didik untuk berperilaku jujur.

Pembiasaan berperilaku jujur di sekolah dapat dilakukan dengan memberikan reward terhadap individu-individu yang berbuat jujur. Pemberian reward ini bisa dilakukan oleh guru tanpa biaya. Contohnya, ketika ada anak yang berbuat jujur dan perilaku baik lainnya dapat direspon dengan memberikan pujian. Pemberian kata-kata pujian sesungguhnya telah menunjukkan reward yang baik, dan anak-anak pada umumnya akan merasa bangga dengan ucapan tersebut. Pada gilirannya, mereka akan berusaha untuk berbuat kebaikan dan perilaku jujur dalam lingkungan sekolah, dan berkembang dalam kehidupannya sehari-hari di rumah dan masyarakat. (4) Mengadakan refleksi yaitu Refleksi merupakan bentuk evaluasi suatu sikap yang harus dilakukan oleh gutu dalam upaya untuk melihat kembali sejauh mana penanaman perilaku kejujuran telah dilaksanakan oleh peserta didik. Refleksi dimaksudkan untuk mengetahui keberhasilan dan kegagalan yang dilakukan selama ini, selanjutnya dijadikan dasar untuk melakukan peningkatan terhadap penanaman kejujuran pada peserta didik. Refleksi sesungguhnya bukan saja dilakukan terhadap peserta didik saja, tetapi harus menyeluruh terhadap setiap individu yang ada di sekolah, seperti guru itu sendiri, kepala sekolah, pegawai, komite sekolah dan bahkan orang tua siswa.

Melalui kegiatan refleksi ini, sekaligus dapat diketahui apakah mereka para personil sekolah telah mampu menerapkan nilai kejujuran tersebut dalam kehidupan sehari-hari, baik di lingkungan sekolah, keluarga, dan masyarakat. (5) Memberikan punishment yaitu pemberian punishment atau hukuman terhadap pelanggaran merupakan salah satu metode yang dapat dilakukan dalam membiasakan peserta didik berperilaku jujur. Hukuman ini harus dicantumkan dengan jelas dalam peraturan yang dibuat sekolah. Namun demikian, hukuman yang diberikan tidak boleh berlebihan, yang justru berdampak tidak baik bagi sekolah. Setiap individu yang berperilaku tidak jujur, hendaknya diberikan hukuman sesuai dengan tingkat resiko dari perbuatan ketidakjujurannya 
Dengan sembilan potensi tersebut, pada akhirnya guru mempunyai kesempatan dan potensi yang baik untuk memberikan penanaman karakter jujur kepada anak didik. Untuk bisa mengarah ke sana, ada beberapa hal yang harus dilakukan guru, yaitu (Yusuf, 1989) dalam (Rochmawati, Nikmah, 2018): Pertama, guru dapat menjadi teladan untuk siswa dalam berperilaku, bertutur kata dan beragama. Kedua, guru seyogyanya mengerti dan menghargai keunikan siswa baik kelebihan maupun kekurangannya, pendapatnya, tidak mencemoohnya, memberikan reward dan pujian yang memadai atas prestasi yang dicapai siswanya. Ketiga, guru membimbing siswanya dengan cara menciptakan suasana kelas yang rileks dan mampu menstimulasi perkembangan siswa, menginformasikan cara belajar efektif, melakukan sosialisasi peraturan sekolah agar dapat dipahami oleh siswa manfaat dan tujuannya, menciptakan budaya belajar dan karakter yang baik dalam proses penanaman karakter jujur kepada anak didik, langkah-langkah yang bisa dilakukan guru adalah sebagai berikut: pertama, mengimplementasikan pembiasaan sikap dan perilaku jujur di sekolah. Untuk menumbuhkan sikap dan perilaku jujur, tidak cukup hanya dibekali pengetahuan dan cerita tentang kejujuran, tetapi dibutuhkan pembiasaan sikap dan perilaku sehari-hari sehingga muncul refleks dalam berperilaku jujur. Oleh karena itu, sekolah memiliki peran yang penting juga seperti hal nya orang tua dalam membentuk karakter kejujuran anak. Ketika orang tua di sekolah memiliki hubungan yang baik dan saling bekerja sama maka pembentukan karakter jujur anak akan mudah untuk dilakukan.

Diagram diatas juga menunjukan bahwa anak tidak menuduh orang lain atau mengatakan hal yang tidak benar terkait orang lain, anak tidak mengambil sesuatu yang bukan miliknya, anak mengembalikan barang yang dipinjam, dan anak mengetahui perbuatan yang tepat dan tidak tepat adalah indikator paling tinggi yang dicapai oleh anak. Artinya anak sudah mengetahui bahwa perilaku tersebut adalah perilaku tidak baik. Indikator tidak menuduh orang lain banyak diperolehh siswa. Yang dimaksud menuduh disini adalah ketika anak diberi toples yang berisi makanan, anak tidak berbicara kepada guru yang dimaksudkan untuk menuduh temannya telah membuka toples tersebut. Sehingga tidak ada anak yang merasa dituduh hal yang tidak dilakukannya. Pencapaian indikator tersebut adalah hal positif yang diharapkan dapat menjadi kebiasaan bagi anak hingga dewasa. Ketika anak terbiasa menuduh orang lain yang tidak sesuai dengan kenyataan hal tersebut akan berdampak negatif baik bagi diri anak maupun bagi orang lain.

Indikator selanjutnya yang dicapai anak adalah anak tidak mengambil sesuatu yang bukan miliknya. Meskipun pada saat treatment dilakukan, anak ditinggalkan oleh guru dan diawasi sama CCTV tidak ada anak yang melakukan pengambilan barang tanpa izin. Artinya setiap anak sudah mengerti arti kepemilikan, mana barang miliknya dan barang milik orang lain. Mengambil barang milik orang lain tentunya bukan perilaku terpuji sehingga kita harus menanamkan perilaku ini kepada anak agar anak tidak mengambil barang orang lain. Akan menjadi masalah besar jika suatu saat nanti anak mengambil barang bukan miliknya, selain anak tidak akan dipercaya oleh orang lain anak juga akan menerima sanksi sosial.

Indikator tentang anak mengembalikan barang yang dipinjamnya berkaitan erat dengan indikator mengambil barang orang lain. Meskipun pada awalnya anak meminta izin untuk meminjam barang tersebut, tetapi ketika anak sudah selesai memakainya dan tidak mengembalikan barang tersebut, hal itu sama dengan mengambil barang orang lain. Ketika anak sukses mencapai indikator ini, maka ini akan menjadi awal yang baik untuk membentuk karakter jujur anak. Indikator terakhir yang dimiliki anak adalah anak mengetahui perbuatan yang tepat dan tidak tepat. Indikator ini menjadikan anak dapat membedakan hal yang boleh dan tidak boleh dilakukan. Seperti halnya dalam penelitian ini, anak tidak boleh membuka toples yang diberikan guru maka ketika sudah ada instruksi seperti itu harusnya anak mengetahui apa yang harus dan tidak harus dilakukan. Sesuai dengan harapan kebanyak anak mampu mencapai indikator ini, oleh sebab itu ketika anak sudah mencapai beberapa indikator tersebut maka anak diharapkan memiliki karakter yang baik.

\section{SIMPULAN}

Berdasarkan hasil penelitian, anak-anak usia 5-6 Tahun di RA At-Taufiq sudah memiliki perilaku kejujuran yang baik. Dari beberapa indikator kejujuran, seluruh anak-anak sudah mengetahui perilaku yang tepat dan tidak tepat. Hanya saja karena karakter dasar anak adalah memiliki rasa ingin tahu yang tinggi, sebagian kecil dari mereka belum dapat mentaati instruksi yang disampaikan oleh guru untuk tidak membuka atau mengambil barang yang belum menjadi miliknya. Namun anak-anak menyadari dan dapat mengakui kesalahan mereka saat mereka berperilaku tidak jujur. Indikator yang 
digunakan dalam penelitian ada sembilan yaitu (1) anak tidak menuduh orang lain atau mengatakan hal yang tidak benar terkait orang lain, (2) anak tidak menutupi kesalahan yang dilakukannya, (3) anak menjelaskan peristiwa sesuai fakta, (4) anak dapat mematuhi aturan, (5) anak tidak mengambil sesuatu yang bukan miliknya, (6) anak meminta izin saat menggunakan/mengambil barang yang bukan miliknya, (7) anak mengembalikan barang yang dipinjam, (8) anak mengetahui perbuatan yang tepat dan tidak tepat, (9) menyadari dan mengakui kesalahannya. Dari kesembilan indikator tersebut anak paling sedikit mencapai indikator anak menyadari dan mengakui kesalahannya dan indikatoryang paling tinggi dicapai anak adalah anak tidak menuduh orang lain atau mengatakan hal yang tidak benar terkait orang lain, anak tidak mengambil sesuatu yang bukan miliknya, anak mengembalikan barang yang dipinjam, dan anak mengetahui perbuatan yang tepat dan tidak tepat. Pencapaian anak tersebut dapat dijadikan acuan untuk mengetahui karakter jujur yang dimiliki anak

\section{UCAPAN TERIMA KASIH}

Kami mengucapkan terimakasih kepada UPI Kampus Tasikmalaya yang telah memberikan bantuan dana penelitian fakultas/pascasarjana/kampus daerah.

\section{DAFTAR PUSTAKA}

Amin, Muhammad. (2017). Peran Guru dalam Menanamkan Nilai Kejujuran pada Lembaga Pendidikan. Jurnal Studi Manajemen Pendidikan, 1(1), 105-124.

Aeni, Nur A dkk. (2017). Pendidikan Karakter antara Teori dan Aplikasi. Bandung: Rizqi Press.

Cooper, Carol, dkk. (2009). Ensiklopedia Perkembangan Anak. Jakarta: Erlangga.

Hurlock, Elizabeth B. (2013). Perkembangan Anak Edisi Keenam. Jakarta: Erlangga.

Kesuma, Darma., dkk. (2011). Pendidikan Karakter Kajian Teori dan Praktik di Sekolah. Bandung: Rosda Karya

Kompasiana. (9 Februari 2018). Humaniora: Degradasi Moralalitas Genmud sebagai Penanda Buruknya Pendidikan Karakter di Indonesia

Lee, K., dkk. (2014). Can Classic Moral Stories Promote Honesty in Children? Psychological Science, 25(8), 1630-1636. https://doi.org/10.1177/0956797614536401

Mansur. (2007). Pendidikan Anak Usia Dini dalam Islam. Yogyakarta: Pustaka Pelajar

Megawangi, Ratna.( 2004). Pendidikan Karakter: Solusi yang Tepat untuk Membangun Bangsa. Jakarta: Indonesia Heritage Foundation.

Messi \& Edi. (2017). Menanamkan Nilai-Nilai Kejujuran di Dalam Kegiatan Madrasah Berasrama (Boarding School). Jurnal Manajemen, Kepemimpinan, dan Supervisi Pendidikan. 1(1), 278290.

M. Lewis, C. Stanger, and M. W. Sullivan, "Deception in 3-year-olds," Developmental Psychology, 25 (3), 439-443, 1989

Narbuko, K \& Achmadi, H.A. (2003). Metode Penelitian. Jakarta: PT Bumi Aksara.

. (2012). Direktorat Jendral Pendidikan Anak Usia Dini Nonformal dan Informal. 2012. Jakarta. pdf.

Novriyansah, dkk. (2018). Studi tentang Perkembangan Karakter Jujur pada Anak Usia Dini. Jurnal Potensia, PGPAUD FKIP UNIB. 2(1), 14-22.

Rofiq \& Ismatun. __ Analisis Peran Keluarga dalam Membentuk Karakter Anak. Diperoleh 5 Desember, 2019, dari https://osf.io > download

Rochmawati, Nikmah. (2018). Peran Guru dan Orang Tua Membentuk Karakter Jujur pada Anak. Jurnal Studi dan Penelitian Pendidikan Islam, 1(2), 1-12.

Santrok, John W. (2007). Perkembangan Anak Edisi Kesebelas Jilid 2. Jakarta: Erlangga.

Sugiyono. (2010). Metode Penelitian Kuantitatif, Kualitatif dan R\&D. Alfabeta. Bandung.

Sujiono, YN. (2010). Konsep Dasar Pendidikan Anak Usia Dini. Jakatra: Indeks Terbuka.

VanderVen, Karen. (2008). Promoting Positive Development in Early Childhood: Building Blocks for A Successful Start. New York:Springer Science and Bussines Media. 